\title{
COMPARING THE GROWTH AND FLOWERING OF SELECTED BASIL (OCIMUM BASILICUM L.) VARIETIES
}

\author{
Renata Nurzyńska-Wierdak \\ Department of Vegetable Growing and Medicinal Plants, Agricultural University, Leszczyńskiego 58, 20-068 Lublin, Poland \\ e-mail: renata.nurzynska@ar.lublin.pl
}

Received: 25.09 .2007

\section{S u m m a r y}

Investigations carried out in 2005-2006 related to the growth, flowering, and yielding of selected basil (Ocimum basilicum L.) varieties. The most important biometric traits, number of days from sowing till flowering, size of fresh and air-dried herb weight, and essential oil content in dried material, were determined. Great morphological and developmental as well as chemical composition differentiation was found for studied basil varieties. Plants of 'Sweet' cv. were characterized by the largest height $(53.4 \mathrm{~cm})$ and side shoot number (16), 'Lemon' - by the largest plant diameter $(42.3 \mathrm{~cm})$. The number of days till flowering depended on weather conditions and the variety, and it amounted from 44 to 126 . Basil flowers were white, pink, and violet. Herb yield depended on the variety and growth conditions. Differences in the amount and yield of essential oil from basil were also recorded. The largest amounts of oil $(1.55 \%)$ were accumulated by 'Bush' cv.

Key words: sweet basil, growth, flowering, yield of fresh and dry herb, essential oil content

\section{INTRODUCTION}

The genus Ocimum is characterized by great species diversity in terms of morphological traits and chemical composition. At present, basil (Ocimum basilicum L.) is widely cultivated in tropical and Mediterranean countries. Green and aromatic leaved varieties are mainly cultivated. Herb and essential oil that has anti-depressive, anti-microbial, and anti-oxidative properties is raw material (M u ra $1 \mathrm{id} \mathrm{h}$ a r a n and Dhan anjay a n, 2004).

Basil is an open and insect pollinated plant. It blooms since June till September and its flowers secrete significant amounts of nectar (J a r o n i ew s k i, 1998, Nurzyńska-Wierdak, 2000). Basil flowers are grouped in 6-10-element sets in pseudo-verticils at the shoot top forming pseudo-spikes. The corolla is white, pale-pink or violet. Buds open during the whole day with higher intensity just before noon. Because basil produces flowers with a short corolla tube, it is an easily accessible nectar source for insects. Mainly honey-bee, solitary-bee and bumble-bee are insects that visit and pollinate basil plants (B ożek, 2000; Chwil, 2003).

The cultivation of basil for fresh or dried leaves and as a decorative plant is particularly common in North America. Simon et al. (1999) reported that over 40 basil varieties can be found on American market. In Poland, only two basil varieties are registered (S e i d le r - Łoży k ow s ka and Kaźmierczak, 2005), but seeding material is not available.

The present study aims at comparing the growth, flowering, and essential oil content in raw basil of several English varieties cultivated under climatic conditions of south-eastern Poland.

\section{MATERIALS AND METHODS}

The studies were carried out in The Experimental Farm Felin (Agricultural University of Lublin) in 2005-2006. Basil of 'New Guinea', 'Lemon', 'Sweet', 'Napoletano', 'Bush', 'Purple Ruffles', var. piperita, and var. lactucoefolium varieties was cultivated from seedlings produced in a heated greenhouse. Seeding material originated from: Chilterns Seeds, Sutton Seeds (cultivated varieties), and from the Botanical Garden of Maria Curie-Skłodowska University in Lublin (botanical varieties). Basil seeds were sown at the beginning of April, and seedlings were planted about May $20^{\text {th }}$ in $50 \times 30 \mathrm{~cm}$ spacing. The experiment was carried out by means of the split-plot method in four replications, planting 20 plants in each replication. Observations of 24 randomly selected plants of each variety relating to flowering dates and intensity were performed during the vegetation period. In general, there were favorable weather conditions, namely in 2005, while at the end 
of May 2006, the temperature decreased to $5-6^{\circ} \mathrm{C}$ for short time. Moreover, during the basil vegetation period of 2006, the precipitation total was much lower than in 2005, similarly as temperatures at the end of May and the beginning of July.

Harvest was made at the beginning of basil flowering by cutting the above-ground part just over the lignified stem fragment. The evaluation of basil growth, leaves number, and yield of fresh herb was also made that time. The raw material was dried under natural conditions, in a dry, dark and ventilated room. Yield of air-dried herb was estimated and then essential oil content was determined in accordance to Polish Pharmacopoeia VI (2002). The achieved results were statistically processed by means of variance analysis for double classification at the significance level of $\alpha=0.05$.

\section{RESULTS}

Significant differentiation was found in the investigated basil traits relating to the plant's height and diameter, the number of main shoots as well as the length and width of leaf blade, (Tab. 1 and 2). The highest plants $(53.4 \mathrm{~cm})$ with the largest number of main shoots (16.0) were produced by 'Sweet', whereas 'Lemon' was characterized by the largest diameter $(42.3 \mathrm{~cm})$. Basil leaves were light green ('Lemon'), through green (majority of varieties) to purple ('Purple Ruffles'). 'Napoletano' produced the significantly largest and 'Bush' significantly smallest leaves as compared to other varieties.

The studied basil varieties significantly differed in the flowering rate, number and length of inflorescences, number of verticils in the main inflorescence as well as flower color (Tab. 3). Plants of 'Bush' variety

Table 1

Characteristics of chosen growth features of studied basil cultivars.

\begin{tabular}{|c|c|c|c|c|c|c|c|c|c|}
\hline \multirow{2}{*}{ Cultivar } & \multicolumn{3}{|c|}{ Plant height $(\mathrm{cm})$} & \multicolumn{3}{|c|}{$\begin{array}{c}\text { Number of branches per } \\
\text { plant }\end{array}$} & \multicolumn{3}{|c|}{ Plant diameter $(\mathrm{cm})$} \\
\hline & 2005 & 2006 & mean & 2005 & 2006 & mean & 2005 & 2006 & mean \\
\hline 'New Guinea' & 26.0 & 39.4 & 32.7 & 14.0 & 11.9 & 13.0 & 28.2 & 39.4 & 33.8 \\
\hline 'Lemon' & 37.8 & 43.8 & 40.8 & 12.8 & 11.7 & 12.3 & 39.2 & 45.0 & 42.3 \\
\hline 'Sweet' & 56.8 & 50.0 & 53.4 & 18.8 & 13.1 & 16.0 & 40.6 & 41.4 & 41.0 \\
\hline 'Napoletano' & 39.4 & 31.4 & 35.4 & 10.2 & 9.2 & 9.7 & 28.0 & 27.8 & 27.9 \\
\hline 'Bush’' & 29.4 & 28.3 & 28.9 & 15.6 & 15.5 & 15.6 & 28.8 & 21.1 & 25.0 \\
\hline 'Purple Ruffles' & 31.8 & 37.7 & 34.8 & 15.0 & 14.4 & 14.7 & 22.4 & 33.2 & 27.8 \\
\hline var. piperita & 50.4 & 43.1 & 46.8 & 13.8 & 11.6 & 12.7 & 45.2 & 37.8 & 41.5 \\
\hline var. lactucoefolium & 59.4 & 42.1 & 50.8 & 15.6 & 9.2 & 12.4 & 44.8 & 31.5 & 38.2 \\
\hline mean & 41.4 & 39.5 & 40.5 & 14.5 & 12.1 & 13.3 & 34.7 & 34.7 & 34.7 \\
\hline \multicolumn{2}{|c|}{$\mathrm{LSD}_{0.05}$ cultivar } & \multicolumn{2}{|l|}{19.6} & \multicolumn{3}{|c|}{3.5} & \multicolumn{3}{|c|}{12.8} \\
\hline
\end{tabular}

Table 2

Characteristics of basil leaves.

\begin{tabular}{|c|c|c|c|c|c|c|c|}
\hline \multirow[t]{2}{*}{ Cultivar } & \multicolumn{3}{|c|}{ Length of leaf blade $(\mathrm{cm})$} & \multicolumn{3}{|c|}{$\begin{array}{l}\text { Width of leaf blade } \\
\qquad(\mathrm{cm})\end{array}$} & \multirow[t]{2}{*}{ Leaf color } \\
\hline & 2005 & 2006 & mean & 2005 & 2006 & mean & \\
\hline 'New Guinea' & 5.6 & 4.0 & 4.8 & 1.6 & 1.9 & 1.8 & $\begin{array}{c}\text { green } \\
\text { nale_oreen }\end{array}$ \\
\hline 'Lemon' & 5.2 & 4.6 & 4.9 & 2.2 & 2.7 & 2.5 & $\begin{array}{l}\text { pale-green } \\
\text { green }\end{array}$ \\
\hline 'Sweet' & 7.4 & 5.4 & 6.4 & 3.6 & 3.2 & 3.4 & $\begin{array}{l}\text { green } \\
\text { green }\end{array}$ \\
\hline 'Napoletano' & 11.2 & 7.4 & 9.3 & 7.2 & 5.0 & 6.1 & $\begin{array}{l}\text { green } \\
\text { green }\end{array}$ \\
\hline 'Bush’ & 3.8 & 2.0 & 2.9 & 1.6 & 1.3 & 1.5 & green \\
\hline 'Purple Ruffles' & 11.2 & 6.0 & 8.6 & 6.4 & 3.8 & 5.1 & $\begin{array}{l}\text { purple } \\
\text { green }\end{array}$ \\
\hline var. piperita & 7.4 & 4.8 & 6.1 & 3.4 & 2.9 & 3.2 & $\begin{array}{l}\text { green } \\
\text { green }\end{array}$ \\
\hline var. lactucoefolium & 6.8 & 8.8 & 7.8 & 3.4 & 8.4 & 5.9 & green \\
\hline mean & 7.3 & 5.4 & 6.4 & 3.7 & 3.5 & 3.6 & \\
\hline $\begin{array}{c}\mathrm{LSD}_{0.05} \text { cultivar } \\
\text { year }\end{array}$ & & $\begin{array}{l}3.2 \\
1.7\end{array}$ & & & $\begin{array}{l}2.6 \\
\text { n.s. }\end{array}$ & & \\
\hline
\end{tabular}


Table 3

Characteristics of basil flowering.

\begin{tabular}{|c|c|c|c|c|c|c|c|c|c|c|c|c|c|}
\hline \multirow{2}{*}{ Cultivar } & \multicolumn{3}{|c|}{ Days to flowering } & \multicolumn{3}{|c|}{$\begin{array}{c}\text { Number of } \\
\text { inflorescences per plant }\end{array}$} & \multicolumn{3}{|c|}{$\begin{array}{c}\text { Length of } \\
\text { inflorescences }(\mathrm{cm})\end{array}$} & \multicolumn{3}{|c|}{$\begin{array}{c}\text { Number of clusters per } \\
\text { main steam }\end{array}$} & \multirow{2}{*}{$\begin{array}{l}\text { Flower } \\
\text { color }\end{array}$} \\
\hline & 2005 & 2006 & mean & 2005 & 2006 & mean & 2005 & 2006 & mean & 2005 & 2006 & mean & \\
\hline 'New Guinea' & 72 & 48 & 60 & 37.6 & 30.1 & 33.9 & 12.6 & 14.4 & 13.5 & 11.0 & 10.6 & 10.8 & pink \\
\hline 'Lemon' & 72 & 44 & 58 & 33.8 & 26.2 & 30.0 & 15.4 & 17.3 & 16.4 & 15.6 & 11.5 & 13.6 & white \\
\hline 'Sweet' & 94 & 50 & 72 & 35.2 & 29.1 & 32.2 & 18.8 & 12.4 & 15.6 & 12.2 & 9.9 & 11.1 & white \\
\hline 'Napoletano' & 87 & 49 & 68 & 31.0 & 28.3 & 29.7 & 13.8 & 7.1 & 10.5 & 17.0 & 7.1 & 12.1 & white \\
\hline 'Bush' & 61 & 49 & 55 & 52.8 & 52.3 & 52.6 & 10.6 & 8.5 & 9.6 & 13.4 & 9.4 & 11.4 & white \\
\hline 'Purple Ruffles' & 126 & 48 & 87 & 16.2 & 22.7 & 19.5 & 12.2 & 13.9 & 13.1 & 10.0 & 9.9 & 10.0 & pale-purple \\
\hline piperita & 67 & 44 & 56 & 41.2 & 41.4 & 41.3 & 16.2 & 15.4 & 15.8 & 14.2 & 10.3 & 12.3 & white \\
\hline lactucoefolium & 58 & 50 & 59 & 42.8 & 39.3 & 41.1 & 15.8 & 13.7 & 14.8 & 15.8 & 9.5 & 12.7 & white \\
\hline mean & 80 & 48 & 64 & 36.3 & 33.7 & 35.0 & 14.4 & 12.8 & 13.6 & 13.7 & 10.0 & 11.9 & \\
\hline $\mathrm{LSD}_{0.05} \mathrm{cl}$ & $\begin{array}{l}\text { tivar } \\
\text { arr }\end{array}$ & $\begin{array}{l}16.0 \\
29.0\end{array}$ & & & $\begin{array}{c}11.2 \\
n . s\end{array}$ & & & 3.4 & & & 2.3 & & \\
\hline
\end{tabular}

Table 4

Plant weight and yield of basil herb.

\begin{tabular}{|c|c|c|c|c|c|c|c|c|c|}
\hline \multirow[t]{2}{*}{ Cultivar } & \multicolumn{3}{|c|}{ Plant weight (g) } & \multicolumn{3}{|c|}{$\begin{array}{l}\text { Yield of fresh herb } \\
\qquad\left(\mathrm{kg} 100 \mathrm{~m}^{2}\right)\end{array}$} & \multicolumn{3}{|c|}{$\begin{array}{l}\text { Yield of air dry herb } \\
\qquad\left(\mathrm{kg} 100 \mathrm{~m}^{2}\right)\end{array}$} \\
\hline & 2005 & 2006 & mean & 2005 & 2006 & mean & 2005 & 2006 & mean \\
\hline 'New Guinea' & 98.2 & 76.8 & 87.5 & 10.4 & 8.5 & 9.5 & 2.3 & 2.0 & 2.2 \\
\hline 'Lemon’ & 100.0 & 110.5 & 105.3 & 10.7 & 12.3 & 11.5 & 2.4 & 2.5 & 2.5 \\
\hline 'Sweet' & 188.0 & 118.7 & 153.4 & 20.0 & 13.2 & 16.6 & 4.4 & 2.6 & 3.5 \\
\hline 'Napoletano' & 156.4 & 87.5 & 122.0 & 16.7 & 9.7 & 13.2 & 2.8 & 2.2 & 2.5 \\
\hline 'Bush' & 141.3 & 75.7 & 108.5 & 15.0 & 8.5 & 11.8 & 3.1 & 1.5 & 2.3 \\
\hline 'Purple Ruffles' & 178.0 & 83.7 & 130.9 & 20.0 & 9.3 & 14.7 & 4.1 & 1.6 & 2.9 \\
\hline var. piperita & 202.9 & 94.4 & 148.7 & 21.6 & 10.5 & 16.1 & 4.4 & 2.1 & 3.3 \\
\hline var. lactucoefolium & 183.1 & 109.2 & 146.2 & 19.5 & 12.2 & 15.9 & 3.9 & 2.5 & 3.2 \\
\hline mean & 156.0 & 94.6 & 125.3 & 16.7 & 10.5 & 13.6 & 3.4 & 2.1 & 2.8 \\
\hline $\mathrm{LSD}_{0.05}$ cultivar & & 23.1 & & & 4.2 & & & 0.9 & \\
\hline year & & 58.4 & & & 6.1 & & & 1.2 & \\
\hline
\end{tabular}

Table 5

Essential oil content and oil efficiency depending on basil cultivar.

\begin{tabular}{|c|c|c|c|c|c|c|c|}
\hline \multirow{2}{*}{ Cultivar } & \multicolumn{3}{|c|}{ Essential oil content (\%) } & \multicolumn{3}{|c|}{$\begin{array}{l}\text { Essential oil efficiency } \\
\text { ( } \mathrm{g} \text { per plant) }\end{array}$} & \multirow[t]{2}{*}{ Essential oil aroma } \\
\hline & 2005 & 2006 & mean & 2005 & 2006 & mean & \\
\hline 'New Guinea' & 1.15 & 1.47 & 1.31 & 0.25 & 0.29 & 0.27 & licorice-anise \\
\hline 'Lemon’ & 0.68 & 1.60 & 1.14 & 0.15 & 0.32 & 0.24 & lemon \\
\hline 'Sweet' & 0.95 & 1.10 & 1.03 & 0.40 & 0.22 & 0.31 & spicy-aromatic \\
\hline 'Napoletano' & 1.03 & 0.80 & 0.92 & 0.28 & 0.16 & 0.22 & spicy-aromatic \\
\hline 'Bush' & 1.15 & 1.95 & 1.55 & 0.35 & 0.39 & 0.37 & spicy-aromatic \\
\hline 'Purple Ruffles' & 0.95 & 1.20 & 1.08 & 0.36 & 0.24 & 0.30 & anise \\
\hline var. piperita & 0.35 & 1.25 & 0.80 & 0.14 & 0.25 & 0.20 & spicy-aromatic \\
\hline var. lactucoefolium & 0.38 & 1.17 & 0.78 & 0.16 & 0.23 & 0.20 & spicy-aromatic \\
\hline mean & 0.83 & 1.32 & 1.07 & 0.26 & 0.26 & 0.26 & \\
\hline $\begin{array}{c}\mathrm{LSD}_{0.05} \text { cultivar } \\
\text { year }\end{array}$ & & $\begin{array}{l}0.16 \\
0.37\end{array}$ & & & $\begin{array}{r}0.13 \\
\text { n.s. }\end{array}$ & & \\
\hline
\end{tabular}


flowered earliest (55 days after sowing), 'Purple Ruffles' latest (after 87 days). The largest number of flowers was recorded in 'Bush', the largest number of verticils and the longest inflorescences in 'Lemon'. A strong dependence between the earliness of basil flowering and weather conditions during cultivation was observed, namely for 'Sweet' and 'Purple Ruffles', the plants which flowered two times earlier in a year with unfavorable thermal conditions. As regards the flowering date, the varieties 'Bush' and lactucoefolium can be considered as less sensitive to weather conditions during cultivation. The white color of flowers dominated, and only the plants of 'New Guinea' produced pink, and 'Purple Ruffles' light-purple flowers.

Basil plant weight as well as yield of fresh and air-dried herb significantly depended on a variety and weather conditions (Tab. 4). 'Sweet' was characterized by the highest, and 'New Guinea' by the lowest mean plant weight and herb yield. Basil cultivated under favorable weather conditions was distinguished by significantly higher weight and yield as compared to those cultivated under worse conditions.

Herb of the studied basil varieties contained from $0.78 \%$ (lactucoefolium) to $1.55 \%$ ('Bush') of essential oils, on average (Tab. 5). It was found that basil plants accumulated significantly more essential oils under less favorable thermal conditions as opposite to more optimum ones. The most apparent differences in essential oil due to weather conditions occurred in basil botanical varieties, the least - in 'Lemon'. The mean efficiency of oil was from 0.20 to $0.37 \mathrm{~g}$ per plant, depending on the variety. Essential oil made from basil herb was distinguished by spice-balsamic, liquor-anise, anise and lemon aroma, which also depended on the variety. Regardless of the main aroma component, basil oil had a very strong and durable scent.

\section{DISCUSSION}

Basil is considered to be a genus with considerable morphological, chemical, and developmental diversity, and the majority of cultivated varieties belong to the species Ocimum basilicum L. Basil varieties classification is mainly based on the type of growth, leaf size and structure; however, its taxonomy is achieved by the presence of many botanical varieties, cultivated varieties, and chemotypes that significantly differ in their morphological traits (Grayer et al. 1996; Simon et al. 1999; Bremner, 1999). A system taking into account also the quantitative and qualitative composition of essential oils may be some kind of help (S i m on et al., 1999). Results of the present investigations confirm great morphological and developmental variability of basil, as well as its sensitivity to unfavorable weather conditions.

The studied basil was characterized by abundant flowering, and depending on the variety, plants flowered from the beginning of June until mid-July. Intensive visits of insects, namely honey-bees and bumble-bees described as visiting and pollinating Lamiaceae plants flowers, were observed before noon (B o ż e k, 2000; 2002; 2003). Bożek (2003) reported that lavender, hyssop, and peppermint plants reacted in a similar way to varied weather conditions; higher temperatures and better insolation accelerated the flowering date and made the flowering duration shorter. Other dependencies were recorded in the case of the studied basil varieties. Worse thermal conditions affected earlier plant flowering for all the investigated basil varieties. However, much smaller differences in the number of days till the start of flowering were observed under these unfavorable weather conditions.

Amounts of essential oil accumulated by basil plants were in a strict association with the conditions in which they were cultivated. Marotti et al. (1996) reported that the content of essential oil in herb of Italian basil varieties was from 0.3 to $0.7 \%$. A set of 36 basil forms originating from the whole world collected by Osińska and Suchorska (1996) was also characterized by a similar oil concentration $(0.3 \%$ to $0.8 \%)$. Basil plants cultivated in middle Africa contained from $0.02 \%$ to $2.1 \%$ of essential oil (Zollo et al., 2006). The varieties investigated in the present study were distinguished by varied essential oil amounts that were, depending on the variety, from $0.35 \%$ to $1.95 \%$. Regardless of the weather conditions, 'Bush' contained the highest content of oil (1.55\%), which was confirmed by other authors ( $\mathrm{Özcan}$ and Chalchat, 2002, Zollo et al. 2006).

\section{CONCLUSIONS}

1. The studied basil varieties differed from one another in their morphological and developmental traits. Different leaf and flower colors make them suitable for decorative purposes. From this point of view, 'Bush' (fine green leaves, dense spherical conformation) and 'purpurascens' (purple leaves and pale-purple flowers) seem to be very interesting.

2. Basil flowers, depending on the variety, are white, pink or pale-purple. The number of inflorescences on a plant is from 19.5 to 52.6 , on average, for the studied varieties. 'Bush' plants flowered earliest, and 'Purple Ruffles' latest.

3. Basil flowering depended on weather conditions. Accelerated transition from vegetative to generative stage may be a result of low temperatures at the beginning of plant growth.

4. The weight of basil plants along with the yield of fresh and air-dried herb significantly depended on the variety and weather conditions. 'Sweet' was characterized by the highest, and 'New Guinea' the lowest mean plant weight and herb yield. 
5. Herb of the investigated basil varieties contained from $0.78 \%$ (lactucoefolium) to $1.55 \%$ ('Bush') of essential oil. Basil accumulated significantly more essential oil during less favorable thermal conditions as compared to more optimum ones. The greatest differences in oil amounts due to weather conditions occurred for basil botanical varieties, the least - for 'Lemon'.

\section{REFERENCES}

Bożek M., 2000. Flower-pollinating insects of 32 species from Lamiaceae family. Pszczeln Zesz Nauk. 44(2): 293-303.

Bożek M., 2002. Flowering Biology and Pollen Flow of Three Species from Genus Salvia L. Ann. UMCS X, sect. EEE, Hortic.: 51-57.

Bożek M., 2003. Blooming, Pollen Flow and Pollinating Insects of Flowers of Hyssopus officinalis L., Lavandula angustifolia Mill. and Mentha piperita L. Ann. UMCS, XIII, sect. EEE, Hortic.: 93-99.

Bremner P., 1999. Basil; the Genus Ocimum. [In:] Raimo Hiltunen and Yvonne Holm Medicinal and Aromatic PlantsIndustrial Profiles, Harwood Academic Publ. (eds.)

Chwil M., 2003. The Biology of Flowering and Nectar Secretion of Ocimum basilicum L. Ann. UMCS, XIII, sect. EEE, Hortic.: 117-122.

Grayer R. J., Kite G. C., Goldstone F. J., Bryan S. E., Paton A., Putievsky E., 1996. Infraspecific taxonomy and essential oil chemotypes in sweet basil, Ocimum basilicum. Phytochem. 43(5): 1033-1039.

Jaroniewski W., 1998. Sweet basil - a medicinal and spicy plant. Wiad Zielar. 6: 14.

Marotti M., Piccaglia R., Giovanelli E., 1996. Differences in Essential Oil Composition of Basil (Ocimum basilicum L.) Italian Cultivars Related to Morphological Characteristic. J Agric Food Chem. 44: 3926-3929.

Muralidharan A., Dhananjayan R. 2004. Cardiac stimulant activity of Ocimum basilicum Linn. Extracts. Indian J. Pharmacol. 38(3): 163-166.

Nurzyńska-Wierdak R. 2000. Results of field experiments of basil plants. Wiad Zielar. 11: 17-18.

Osińska E., Suchorska K. 1996. Estimation of morphological, developmental and chemical variability of various forms of sweet basil (Ocimum basilicum L.) [In:] proceedings of the $6^{\text {th }}$ Polish Conference of Plant Breeders. Febr 15-16, Kraków: 407- 415.
Özcan M., Chalchat J. C. 2002. Essential oil composition of Ocimum basilicum L. and Ocimum minimum L. in Turkey. Food Sci. 20(6): 223-228.

Polish Pharmakopoeia VI. 2002. Warszawa.

Seidler-Łożykowska K., Kaźmierczak K., 2005. The new polish cultivars of sweet basil (Ocimum basilicum). Herba Pol. (suppl. 1) 51, 85.

Simon J. E., Morales M. R., Phippen W. B., Fontem Vieira R., Hao Z., 1999. Basil: A source of aroma compounds and a popular culinary and ornamental herb. [In:] Janick J. Perspectives on new crops and new uses. ASHS Press, (eds ) Alexandria, VA: 499-504.

Zollo A., Avlessi F., Alitonou G. A., 2006. Variability in the Chemical Compositions of the Essential Oils of Five Ocimum Species from Tropical African Area. JEOR, 18, 194-199.

\section{Porównanie wzrostu i kwitnienia wybranych} odmian bazylii pospolitej (Ocimum basilicum L.)

\section{Streszczenie}

Badania przeprowadzone $\mathrm{w}$ latach 2005-2006 dotyczyły wzrostu, kwitnienia i plonowania wybranych odmian bazylii pospolitej (Ocimum basilicum L.). Określono najważniejsze cechy biometryczne roślin, liczbę dni od wysiewu do zakwitnięcia oraz wielkość plonu świeżej i powietrznie suchej masy ziela, jak również zawartość olejku eterycznego w wysuszonym surowcu. Stwierdzono duże zróżnicowanie morfologiczno-rozwojowe oraz składu chemicznego surowca badanych odmian bazylii. Największą wysokością $(53,4 \mathrm{~cm})$ i liczbą rozgałęzień (16 szt.) charakteryzowały się rośliny odmiany 'Sweet', największą średnicą $(42,3 \mathrm{~cm})$ odznaczały się rośliny odmiany 'Lemon'. Liczba dni do zakwitnięcia była uzależniona od warunków pogodowych oraz odmiany i wynosiła od 44 do 126 . Kwiaty bazylii miały barwę białą, różową i fioletową. Plon ziela zależny był od odmiany i warunków wzrostu. Wykazano różnice w ilości i wydajności olejku eterycznego bazylii. Najwięcej olejku (1,55\%) gromadziły rośliny odmiany 'Bush'. 
